\title{
Analisis Percepatan Tanah Maksimum, Intensitas Maksimum Dan Periode Ulang Gempa Untuk Menentukan Tingkat Kerentanan Seismik Di Jawa Barat (Periode Data Gempa Tahun 1974-2016)
}

\author{
Elza Anisa Suwandi ${ }^{1 . *}$, Indriana Lucky Sari², Waslaluddin ${ }^{1}$ \\ ${ }^{1}$ Departemen Pendidikan Fisika, Universitas Pendidikan Indonesia \\ Jl. Dr. Setiabudhi No. 299 Bandung 40154 \\ ${ }^{2} \mathrm{BMKG}$, Jl. Cemara No. 66 , Bandung \\ *Penulis Penanggung Jawab. Email: elzaanisas@gmail.com
}

\begin{abstract}
ABSTRAK
Penelitian ini bertujuan untuk menentukan tingkat kerentanan seismik di Jawa Barat berdasarkan data gempa bumi periode tahun 1974 - 2016 dengan $\mathrm{Ms} \geq 4.0$ SR yang diperoleh dari katalog gempa NEIC-USGS pada batasan wilayah

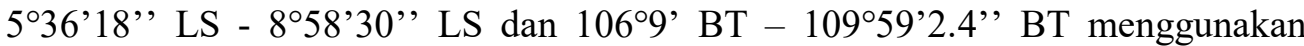
Metode Donovan dan Metode Matuschka. Penelitian ini dilakukan terhadap 1543 titik pengamatan. Sedangkan untuk menentukan periode ulang gempa, sebelumnya dilakukan pembagian wilayah menjadi 5 wilayah dan menentukan $b$ value juga indeks seismisitas terlebih dahulu menggunakan Metode Likelihood. Dari hasil analisis menunjukkan bahwa percepatan tanah maksimum Metode Donovan berkisar antara $27.76 \mathrm{Gal}-110.01 \mathrm{Gal}$ dan intensitas gempa maksimumnya VII MMI - VIII MMI. Sedangkan, percepatan tanah maksimum Metode Matuschka berkisar antara $69.16 \mathrm{Gal}$ - 229.55 Gal dan intensitas gempa maksimumnya VI MMI - VIII MMI. Berdasarkan hasil kedua metode tersebut dapat dikorelasikan dengan frekuensi gempa dan event gempa yang merusak di Jawa Barat dari rentang 42 tahun, didapat metode yang sesuai dengan wilayah keadaan Jawa Barat yaitu Metode Matuschka. Selain itu diperoleh periode ulang gempa berdasarkan $b$ value yang berkisar antara $0.40-0.79$ dan indeks seismisitas yang berkisar antara $0.21-0.85$ yaitu 33 - 125 tahun. Tingkat kerentanan seismik tertinggi di Jawa
\end{abstract}


Barat berada di daerah Cianjur, kecamatan Cidaun tepatnya pada koordinat 7²8'39.047', LS dan 107'16’44.213”, BT. Tingginya kerentanan seismik diakibatkan oleh tingginya nilai percepatan tanah maksimum, intensitas maksimum gempa dan periode ulang gempa yang singkat pada daerah tersebut.

Kata Kunci : Tingkat Kerentanan Seismik, Percepatan Tanah Maksimum, Intensitas Maksimum Gempa, Periode Ulang Gempa

\begin{abstract}
This research aims to determine the level of seismic vulnerability in West Java based on earthquake data period 1974 - 2016 with Ms $\geq 4.0$ SR Obtained from the NEIC-USGS earthquake catalog on the territorial boundaries $5^{\circ} 36^{\prime} 18^{\prime \prime}$ LS - 8 ${ }^{\circ} 58^{\prime} 30^{\prime \prime}$ LS dan $106^{\circ} 9^{\prime}$ BT - 109'59'2.4' BT using the Donovan Method and the Matuschka Method. The study was conducted on 1543 observation points. Meanwhile, to determine the return period of the earthquake, previously done division into 5 areas and determine the $\mathrm{b}$ value also seismicity index first using Likelihood Method. From the analysis results show that the maximum land acceleration Donovan Method ranged between $27.76 \mathrm{Gal}-110.01 \mathrm{Gal}$ and maximum earthquake intensity VII MMI - VIII MMI. Meanwhile, the maximum ground acceleration Matuschka method ranges between $69.16 \mathrm{Gal}$ - 229.55 Gal and maximum earthquake intensity VI MMI - VIII MMI. Based on the results of both methods can be correlated with the frequency of earthquakes and destructive earthquake events in West Java from the span of 42 years, the method obtained in accordance with the region of West Java circumstances is Matuschka method. In addition, the earthquake return period based on $\mathrm{b}$ values ranging from 0.40 to 0.79 and seismicity index ranging from 0.21 to 0.85 is $33-125$ years. The highest level of seismic vulnerability in West Java is located in Cianjur area, Cidaun sub-district precisely in coordinates $7^{\circ} 28^{\prime} 39.047^{\prime \prime}$ LS dan $107^{\circ} 16^{\prime} 44.213^{\prime \prime}$ BT. The high seismic vulnerability is due to the high maximum land acceleration rate, maximum intensity of the earthquake and short period of earthquake repetition in the area.
\end{abstract}

Keywords : Seismic Vulnerability Level, Peak Ground Acceleration, Maximum Intensity of Earthquake, Earthquake Re-Period 


\section{Pendahuluan}

Di bagian barat Indonesia tepatnya di Pulau Jawa merupakan Pulau yang terletak diantara pertemuan lempenglempeng tektonik utama. Khususnya pada bagian selatan Pulau Jawa, pertemuan lempeng-lempeng tersebut membentuk zona subduksi, yaitu pertemuan antara lempeng Eurasia yang berada di sebelah utara dengan lempeng Indo-Australia yang berada di sebelah selatan. Wilayah Jawa Barat merupakan salah satu wilayah yang berada di sekitar zona subduksi tersebut. Selain itu, di wilayah Jawa Barat juga terdapat zona patahan (sesar geser) di bawah permukaannya. Hal ini menunjukkan wilayah Jawa Barat merupakan wilayah yang cukup kompleks karena terdapat zona subduksi dan zona patahan yang menjadi penyebab terjadinya gempa bumi (Akademi Meteorologi Klimatologi Geofisika, 2011).

Secara garis besar intensitas atau tingkat kerusakan yang terjadi akibat gempa bergantung dari kekuatan dan kualitas bangunan, kondisi geologi dan geotektonik lokasi bangunan, percepatan tanah serta periode ulang gempa yang terjadi pada daerah lokasi gempabumi. (Haris, 2013). Telah banyak penelitian mengenai tingkat kerentanan seismik yang didasarkan pada percepatan tanah maksimum, intensitas maksimum maupun periode ulang gempa. Penelitian mengenai percepatan tanah maksimum dan intensitas maksimum gempa telah dilakukan dengan berbagai metode diantaranya memakai metode Gutenberg - Richter, Murphy - O’brien dan Mc. Guirre. Dimana metode tersebut berdasarkan data - data dari parameter gempabumi (Edwiza, 2008). Sedangkan penelitian mengenai periode ulang gempa telah dilakukan dengan beberapa metode yaitu metode least-square dan metode Likelihood. Untuk Indonesia sendiri belum terdapat metode pasti, oleh karena itu metode yang digunakan nantinya mengadopsi metode yang telah digunakan oleh peneliti - peneliti sebelumnya. Penelitian - penelitian mengenai perolehan metode yang telah dilakukan oleh banyak ahli sebelumnya dan menghasilkan sejumlah metode yang berbeda hasil serta keakuratannya (Sari, 2012). Sehingga dalam penelitian ini, Metode Donovan (1973) dan Matuschka (1980) dapat digunakan untuk menentukan percepatan tanah maksimum dan intensitas maksimum gempa (Himawan, 2002). Sedangkan untuk menentukan periode 
ulang gempa digunakan metode Likelihood karena Menurut Utsu (1961) metode tersebut lebih baik daripada metode least - square khusunsnya untuk jumlah gempa $(\mathrm{N})$ yang kecil.

Metode Donovan (1973) dan Matuschka (1980) mempunyai bentuk persamaan yang diadopsi dari Metode Esteva (1970) seperti persamaan 1 dan 2 sebagai berikut,

$$
\begin{aligned}
\alpha_{\text {donovan }}= & 1080 \cdot e^{0.5 M} \cdot(R \\
& +25)^{-1.32} \\
\alpha_{\text {matuschka }}= & 119 \cdot e^{0.81 M} \cdot(R \\
& +25)^{-1.15}
\end{aligned}
$$

Dimana :

$\alpha_{\text {donovan }}=$ percepatan tanah pada permukaan (gal) metode Donovan

$\alpha_{\text {matuschka }}=$ percepatan tanah pada permukaan (gal) metode Matuschka

$M \quad=$ magnitudo permukaan (SR)

$R \quad=$ jarak hiposenter $(\mathrm{km})$

Konstanta pada Metode Donovan didasarkan pada catatan gempa San Fernando (9/2/1971) dan digunakan pada jenis tanah keras di Amerika. Sedangkan konstanta pada Metode Matuschka digunakan pada jenis tanah lunak di New Zealand. Pada konstanta nilai " 25 " di adopsi dari Metode Esteva. (Douglas, 2011).

Adanya hubungan antara intensitas dan percepatan tanah dikarenakan dengan semakin besarnya nilai percepatan getaran tanah yang pernah terjadi di suatu tempat, semakin besar bahaya dan resiko gempabumi yang

\begin{tabular}{|c|c|c|c|}
\hline No. & $\begin{array}{l}\text { Tingkat } \\
\text { Resiko }\end{array}$ & $\begin{array}{l}\text { Percepatan } \\
\text { Tanah } \\
\text { Maks. } \\
\text { (Gal) }\end{array}$ & $\begin{array}{l}\text { Intensitas } \\
\text { Gempa } \\
\text { Maks. } \\
\text { (MMI) }\end{array}$ \\
\hline 1. & $\begin{array}{l}\text { Resiko } \\
\text { sangat } \\
\text { kecil }\end{array}$ & $<25$ & $<\mathrm{VI}$ \\
\hline 2. & $\begin{array}{l}\text { Resiko } \\
\text { kecil }\end{array}$ & $25-50$ & VI - VII \\
\hline 3. & $\begin{array}{l}\text { Resiko } \\
\text { sedang } \\
\text { satu }\end{array}$ & $50-75$ & VII - VIII \\
\hline 4. & $\begin{array}{l}\text { Resiko } \\
\text { sedang } \\
\text { dua }\end{array}$ & $75-100$ & VII - VIII \\
\hline 5. & $\begin{array}{l}\text { Resiko } \\
\text { sedang } \\
\text { tiga }\end{array}$ & $100-125$ & VII - VIII \\
\hline 6. & $\begin{array}{l}\text { Resiko } \\
\text { besar } \\
\text { satu }\end{array}$ & $125-150$ & VIII - IX \\
\hline 7. & $\begin{array}{l}\text { Resiko } \\
\text { besar } \\
\text { dua }\end{array}$ & $150-200$ & VIII - IX \\
\hline 8. & $\begin{array}{l}\text { Resiko } \\
\text { besar } \\
\text { tiga }\end{array}$ & $200-300$ & VIII - IX \\
\hline 9. & $\begin{array}{l}\text { Resiko } \\
\text { sangat } \\
\text { besar } \\
\text { satu }\end{array}$ & $300-600$ & IX $-\mathrm{X}$ \\
\hline
\end{tabular}
mungkin terjadi (Tabel 1).

Tabel 1. Tingkat Resiko Gempa (Fauzi. dkk, 2012) 


\begin{tabular}{llll}
\hline 10. & $\begin{array}{l}\text { Resiko } \\
\text { sangat } \\
\text { besar } \\
\text { dua }\end{array}$ & & \\
\hline
\end{tabular}

Hubungan antara intensitas dengan percepatan tanah menurut metode Donovan (1973) dan metode Matuschka (1980) yaitu dengan persamaan 3 dan persamaan 4 sebagai berikut :

$$
\begin{gathered}
\log \alpha_{\text {donovan }}=\frac{1}{3} \cdot I-\frac{1}{2} \\
\log \alpha_{\text {matuschka }}=\frac{1}{4} \cdot I+\frac{1}{4}
\end{gathered}
$$

Dimana :

$\alpha_{\text {donovan }}=$ percepatan tanah permukaan (gal) metode donovan

$\alpha_{\text {matuschka }}=$ percepatan tanah permukaan (gal) metode matuschka

$$
\text { I }=\text { intensitas (skala MMI) }
$$

(Himawan, 2002).

Periode ulang gempa bumi diperoleh dengan mengetahui nilai parameter keaktifan gempa bumi yaitu a menyatakan keadaan seismisitas dan $\mathrm{b}$ menyatakan keadaan tektonik. Metode yang dapat digunakan untuk menghitung parameter keaktifan gempa bumi salah satunya adalah metode Likelihood. Metode ini mempunyai keunggulan, dimana dalam menghitung secara statistik nilai parameter keaktifan gempa bumi, kelas interval magnitudo dapat diatur sedemikian rupa untuk menghindari kekosongan magnitudo pada kelas interval terntentu.

Dalam metode Likelihood nilai $a$ dan $b$ dapat diperoleh dari persamaan 5 dan 6 ,

$$
\begin{gathered}
\hat{b}=\frac{\log e}{\bar{M}-M_{0}} \\
\hat{a}=\log N+\log (\hat{b} \ln 10) \\
+M_{0} \hat{b} ; M \geq M_{0}
\end{gathered}
$$

Dengan $\bar{M}$ adalah magnitudo rata - rata gempa, $M_{0}$ adalah magnitudo minimum dan $\mathrm{N}$ adalah jumlah gempa dengan magnitudo lebih atau sama dengan 4.0 $\mathrm{SR}(\mathrm{M} \geq 4 \mathrm{SR})$.

Menurut Peter (1965) indeks seismisitas gempa dengan magnitudo besar atau sama dengan 4.0 SR $\left(N_{1}(M \geq 4.0)\right.$ menggambarkan total kejadian gempa bumi rata - rata pertahun dan dapat ditentukan berdasarkan persamaan 7 ,

$$
N_{1}(M \geq 4.0)=10^{\hat{a}_{1}^{\prime}-4.0 \hat{b}}
$$

Dengan $\quad \hat{a}^{\prime}=\hat{a}-\log (\hat{b} \ln 10)$.

Selanjutnya probabilitas kejadian gempa bumi dapat ditentukan dari persamaan 8 ,

$$
P(M, T)=\left(1-e^{-N_{1}(M) T}\right)
$$


Rata-rata tahunan kumulatif jumlah gempa denga $\mathrm{M}$ paling besar dapat ditentukan dari persamaan 9,

$$
N_{1}^{(M)}=N_{1}^{(M \geq 4.0)} \cdot 10^{-2 \hat{b}}
$$

Dengan diperoleh $\mathrm{N}_{1}(\mathrm{M})$ dapat dihitung nilai rata-rata periode ulang dari gempa bumi merusak dapat ditentukan dari persamaan 10 ,

$$
\Theta=\frac{1}{N_{1} M}
$$

(Budiman, 2011)

\section{Metode Percobaan}

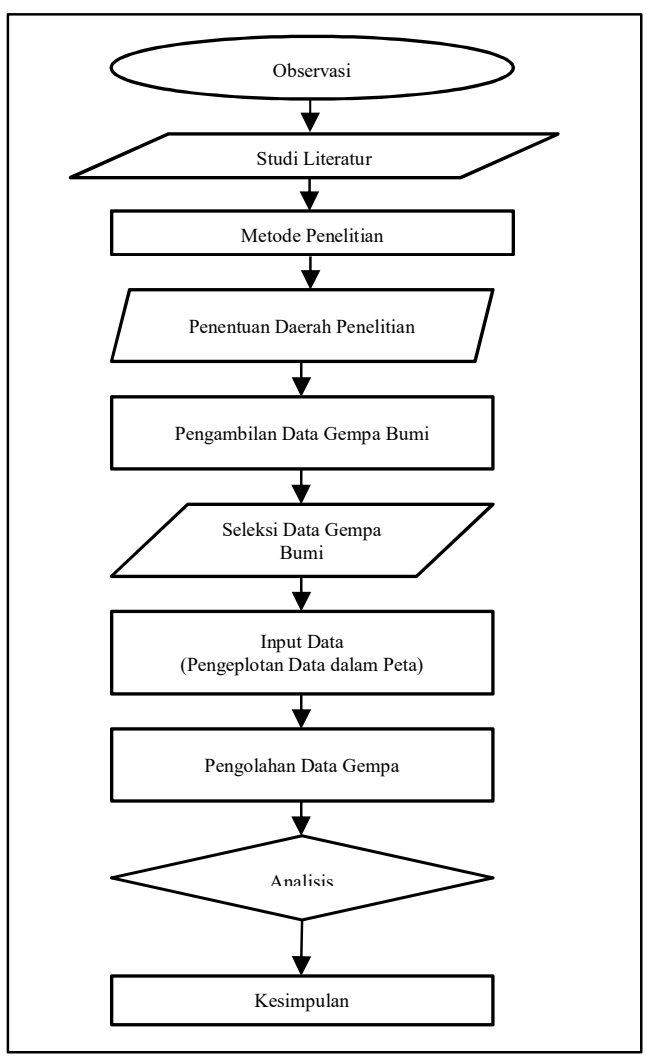

Gambar 1. Diagram Alur Penelitian
Data penelitian diperoleh dari katalog gempa yang disediakan oleh NEIC - USGS dalam kurun waktu 42 tahun dalam batasan koordinat $5^{\circ} 36^{\prime} 18^{\prime}$, LS - 8'58'30' LS dan 106 9' BT 10959'2.4'” BT dengan magnitudo $\mathrm{Ms} \geq 4.0$ SR dan kedalaman gempa $0-$ $330 \mathrm{Km}$.

Dalam penelitian data dilakukan beberapa langkah sistematis untuk menentukan percepatan tanah maksimum dan intensitas maksimum gempa sebagai berikut,

1. Menyusun data historis gempa bumi pada daerah Jawa Barat tahun 1974 - 2016 berdasarkan latitud, longitud, magnitudo dan kedalaman dengan batasan wilayah, diambil data gempa bumi dari $0-9.9$ SR dan digambar peta seismisitasnya.

2. Konversi Jenis Magnitudo ke Magnitudo Permukaan (Ms) (Tabel 2).

Tabel 2. Korelasi Konversi Antara Beberapa Skala Magnitudo Untuk Wilayah Indonesia (Irsyam dkk, 2010) 


\begin{tabular}{c} 
Korelasi Konversi \\
\hline $\mathrm{Mw}=0.143 \mathrm{Ms}^{2}-1.051 \mathrm{Ms}+7.285$ \\
\hline $\mathrm{Mw}=0.114 \mathrm{mb}^{2}-0.556 \mathrm{mb}+5.560$ \\
\hline $\mathrm{Mw}=0.787 \mathrm{M}_{\mathrm{E}}-1.537$ \\
$\mathrm{mb}=0.125 \mathrm{M}_{\mathrm{L}}^{2}-0.389 \mathrm{M}_{\mathrm{L}}-3.51$ \\
\hline $\mathrm{M}_{\mathrm{L}}=0.717 \mathrm{M}_{\mathrm{D}}+1.003$
\end{tabular}

3. Membagi Jawa Barat menjadi beberapa grid, masing-masing grid $0.5 \times 0.5^{\circ}$ dengan menggunakan aplikasi Sistem Informasi Geografis (SIG) yaitu software Arc GIS 10.0. Berikut hasil grid $0.15 \times 0.15^{\circ}$ :

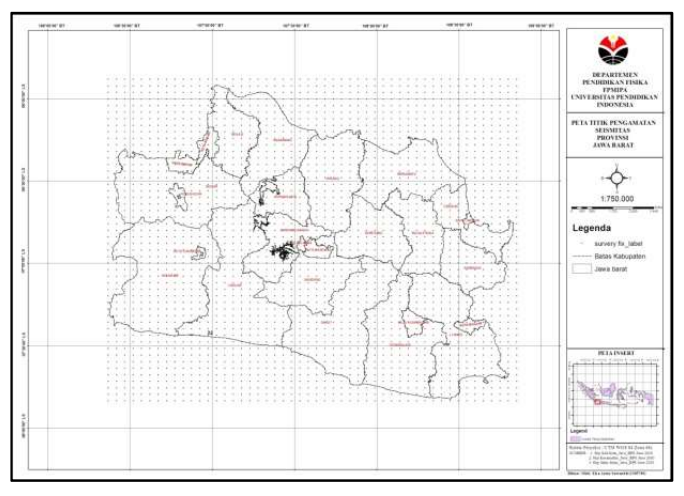

Gambar 2. Titik Pengamatan di Jawa Barat

4. Menghitung jarak episenter dengan menggunakan persamaan 11 ,
$\Delta$

$=\operatorname{arcos} . \sin l a t 1 \cdot \sin l a t 2$

$+\cos$ lat $1 . \cos$ lat $2 \cdot \cos$ long

- long $2 . R$

$\Delta \quad=$ jarak episenter

lat1 = latitude episenter

lat2 = latitude titik pengamatan

long 1 = longitude episenter

long 2 = longitude titik pengamatan

$R \quad=$ jari-jari bumi $(6378 \mathrm{~km})$

5. Menghitung jarak hiposenter dengan menggunakan persamaan 12 ,

$$
\begin{aligned}
& R=\sqrt{\Delta^{2}+h^{2}} \\
& \mathrm{~h}=\operatorname{kedalaman}(\mathrm{km})
\end{aligned}
$$

6. Menghitung nilai percepatan tanah maksimum di tiap titik grid pengamatan dengan menggunakan model empiris Donovan dan Matuschka sesuai dengan persamaan (1) dan (2).

7. Menghitung nilai intensitas gempa maksimum di tiap titik grid pengamatan dengan menggunakan model empiris Donovan dan Matuschka sesuai dengan persamaan (3) dan (4). 
8. Kemudian pada setiap tempat (titik grid) diambil harga maksimumnya sehingga diperoleh harga percepatan tanah maksimum dan intensitas maksimum gempa pada tempat tersebut.

9. Membuat peta kontur percepatan tanah maksimum dan intensitas maksimum gempa dengan menggunakan aplikasi Sistem Informasi Geografis (SIG) yaitu software Arc GIS 10.0.

10. Membuat grafik hubungan antara intensitas maksimum gempa dan percepatan tanah maksimum.

Sedangkan dalam penelitian data untuk menentukan periode ulang gempa dilakukan beberapa langkah sistematis sebagai berikut,

1. Membagi wilayah menjadi 5 bagian.

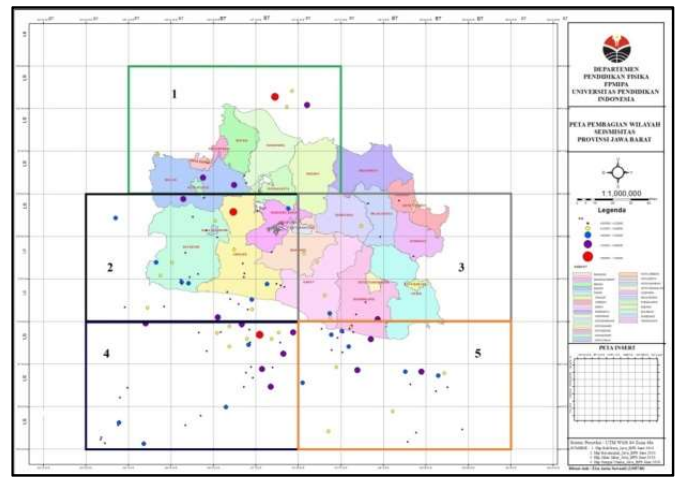

Gambar 3. Pembagian Wilayah
2. Memilah data magnitudo dan frekuensi gempa bumi yang terjadi pada lokasi penelitian sesuai dengan koordinatnya.

3. Menghitung frekuensi kumulatif berdasarkan magnitudonya.

4. Menentukan nilai $b$ value dengan menggunakan metode likelihood maksimum dari persamaan (5).

5. Menentukan indeks seismisitas dengan menggunakan persamaan (6) dan (7).

6. Menentukan probabilitas gempa bumi dan periode ulang gempa dengan menggunakan persamaan (8), (9) dan (10).

\section{Hasil Dan Pembahasan}

Dari hasil perhitungan ini diketahui nilai percepatan tanah maksimum di Jawa Barat berkisar antara $27.76 \mathrm{Gal}-110.01$ Gal dan nilai intensitas maksimum gempanya berkisar antara VI MMI VIII MMI dengan metode Donovan. Sedangkan untuk metode Matuschka diketahui nilai percepatan tanah maksimum di Jawa Barat berkisar antara 69.16 Gal - 229.55 Gal dan nilai intensitas maksimum gempanya berkisar antara VI MMI - VIII MMI. 
Pola percepatan tanah maksimum dan intensitas maksimum gempa dari kedua metode digambarkan dalam peta percepatan tanah maksimum dan intensitas maksimum gempa menggunakan aplikasi Sistem Informasi Geografi (SIG) pada Gambar 4, Gambar 5, Gambar 6, Gambar 7.

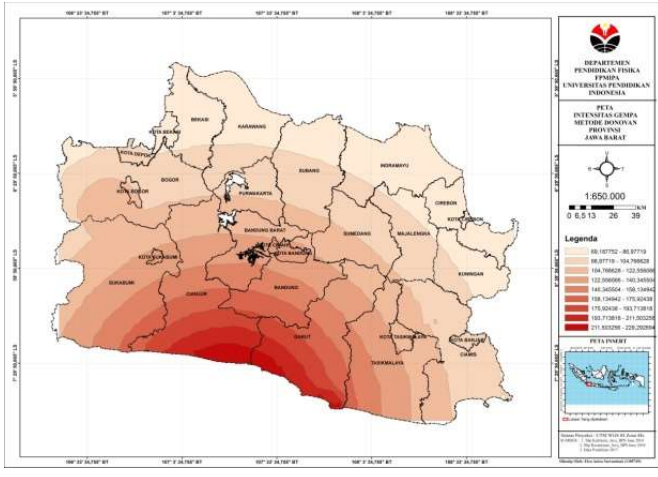

Gambar 8. Peta Percepatan Tanah

Maksimum Metode Matuschka

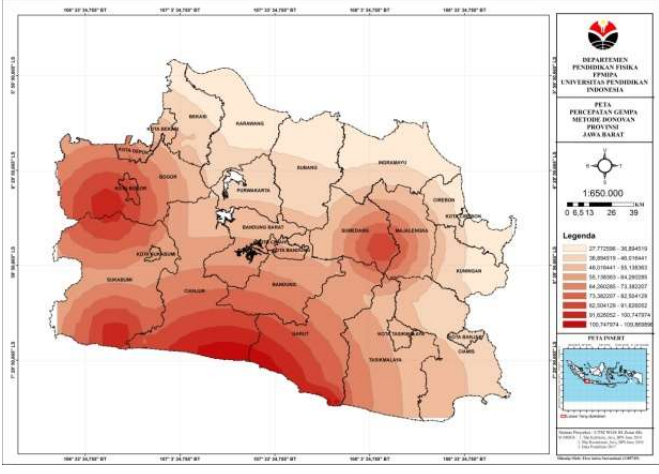

Gambar 6. Peta Percepatan Tanah

Maksimum Metode Donovan

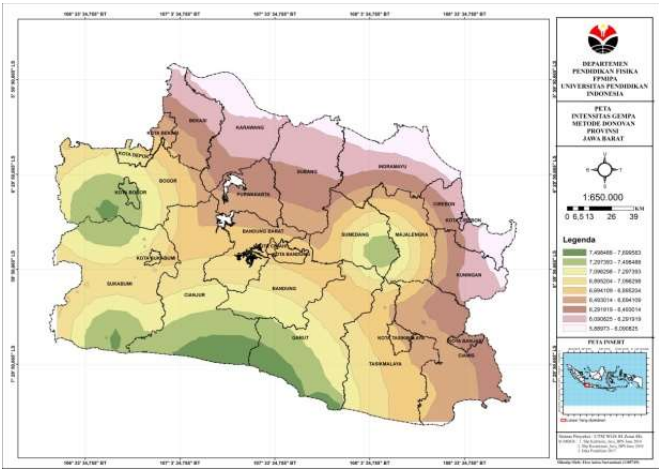

Gambar 7. Peta Intensitas Maksimum Gempa Metode Donovan

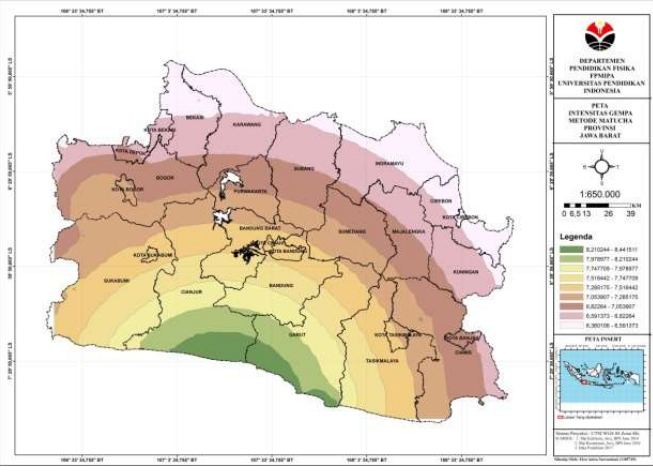

Gambar 9. Peta Intensitas Maksimum

Gempa Metode Matuschka

Untuk hasil perhitungan kedua metode, dari hasil intensitas maksimum gempa keduanya relatif sama, namun pada nilai percepatan tanah maksimum terdapat perbedaan nilai percepatan tanah yang bekisar antara $41.4 \mathrm{Gal}$ dan 119.54 Gal. Hal ini terjadi karena penggunaan metode perhitungan percepatan tanah maksimum dan 
intensitas maksimum gempa yang berbeda.

Berdasarkan hasil perhitungan dan pemetaan untuk percepatan tanah maksimum dan intensitas maksimum gempa dari kedua metode diketahui bahwa nilai tertinggi percepatan tanah maksimum dan intensitas maksimum gempa berada pada grid 468 di koordinat 7²8’39.047 LS dan 107'16’44.213’' BT tepatnya berada di wilayah kabupaten Cianjur, kecamatan Cidaun. Selain daerah tersebut, daerah lain di Jawa Barat bagian selatan yang memiliki nilai percepatan tanah maksimum dan intensitas maksimum gempa yang tinggi adalah Garut, Bandung, Sukabumi dan Tasikmalaya. Sedangkan untuk daerah Bekasi, Karawang, Indramayu dan Cirebon mempunyai nilai percepatan tanah maksimum dan intensitas maksimum gempa yang paling kecil.

Tingginya nilai percepatan tanah maksimum dan intensitas maksimum gempa di daerah-daerah tersebut sangat dipengaruhi oleh event gempa yang merusak yang terjadi pada 2 September 2009 dengan pusat gempa berada di Samudera Hindia $\left(7.78^{\circ}\right.$ LS dan $107.30^{\circ}$ BT) pada kedalaman $46 \mathrm{~km}$ barat daya
Tasikmalaya, gempa ini ber-magnitudo 7.07 SR.

Dilihat dari kondisi geologi wilayah dengan nilai percepatan tanah maksimum dan intensitas maksimum gempa yang paling tinggi yaitu Kecamatan Cidaun, Kabupaten Cianjur, daerah tersebut termasuk dalam Zona Pegunungan Selatan. Zona Pegunungan Selatan merupakan dataran tinggi (plateu) berbentuk segitiga dan puncaknya di sekitar Bandung dan memanjang dari barat ke timur, mulai dari Pangandaran bagian barat sampai ke Nusakambangan bagian timur. Secara keseluruhan zona ini merupakan suatu geantiklin yang agak landai dan telah miring beberapa derajat ke arah Selatan. Batuan yang terkandung pada kecamatan cidaun merupakan batuan aluvium dan endapan pantai berupa lempung, lanau, pasir dan kerikil (Qha). Endapan tersebut merupakan endapan kuarter terlihat pada yang pada umumnya bersifat urai, lepas, belum kompak (unconsolidated) dan memperkuat efek goncangan gempabumi, sehingga rawan terhadap gempabumi.

Daerah Cianjur juga merupakan kawasan yang berada di atas zona subduksi, yaitu pertemuan antara lempeng Eurasia yang 
berada sebelah utara dengan lempeng Indo-Australia yang berada di sebelah selatan yang berakibat daerah Cianjur berada di atas jalur patahan yang menyebabkan gempa.

Dengan diperolehnya nilai percepatan tanah maksimum dan intensitas tanah maksimum gempa di Jawa Barat ini maka dapat diketahui hubungan antara percepatan tanah maksimum terhadap intensitas maksimum gempa. Semakin tinggi nilai intensitas maksimum gempa maka semakin tinggi pula nilai percepatan tanah maksimumnya, sehingga terdapat suatu hubungan sebanding antara nilai intensitas maksimum gempa dan percepatan tanah maksimumnya. Hubungan nilai intensitas maksimum gempa dan percepatan tanah maksimum dapat dilihat pada Gambar 10.

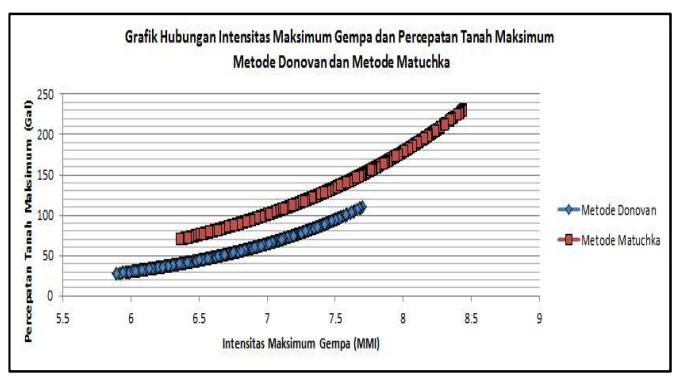

Gambar 10. Grafik Hubungan Intensitas

Maksimum Gempa dan Percepatan

Tanah Maksimum Metode Donovan dan Metode Matuschka.
Dengan menggunakan hasil perhitungan percepatan tanah maksimum dan intensitas maksimum gempa dapat ditentukan tingkat kerentanan seismik yang diakibatkan oleh aktivitas tektonik pada setiap titik pengamatan di Jawa Barat terlihat pada Tabel 3 dan Tabel 4.

Tabel 3. Tingkat kerentan seismik setiap daerah di Jawa Barat (Metode Donovan)

\begin{tabular}{cc}
\hline Daerah & $\begin{array}{c}\text { Tingkat Kerentanan } \\
\text { Seismik }\end{array}$ \\
\hline Bandung & $\begin{array}{c}\text { Resiko kecil - Resiko } \\
\text { sedang satu }\end{array}$ \\
\hline Bekasi & $\begin{array}{c}\text { Resiko kecil - Resiko } \\
\text { sedang satu }\end{array}$ \\
\hline Bogor & $\begin{array}{c}\text { Resiko sedang satu - } \\
\text { Resiko sedang dua }\end{array}$ \\
\hline Ciamis & $\begin{array}{c}\text { Resiko kecil - Resiko } \\
\text { sedang satu }\end{array}$ \\
\hline Cianjur & $\begin{array}{c}\text { Resiko sedang satu - } \\
\text { Resiko sedang tiga }\end{array}$ \\
\hline Cimahi & $\begin{array}{c}\text { Resiko sedang satu - } \\
\text { Resiko sedang satu }\end{array}$ \\
\hline Cirebon & $\begin{array}{c}\text { Resiko sangat kecil - } \\
\text { Resiko kecil }\end{array}$ \\
\hline Garut & $\begin{array}{c}\text { Resiko sedang satu - } \\
\text { Resiko sedang tiga }\end{array}$ \\
\hline Kuningan & Resiko sangat kecil - \\
& Resiko kecil \\
\hline Ramang & Resiko sangat kecil - kecil \\
& Resiko kecil \\
\hline
\end{tabular}




\begin{tabular}{cc} 
Majalengka & $\begin{array}{c}\text { Resiko sedang satu - } \\
\text { Resiko sedang dua }\end{array}$ \\
\hline Purwakarta & Resiko kecil \\
\hline Subang & Resiko kecil \\
\hline Sukabumi & $\begin{array}{c}\text { Resiko sedang satu - } \\
\text { Resiko sedang dua }\end{array}$ \\
\hline Sumedang & $\begin{array}{c}\text { Resiko kecil - Resiko } \\
\text { sedang dua }\end{array}$ \\
\hline Tasikmalaya & $\begin{array}{c}\text { Resiko kecil - Resiko } \\
\text { sedang satu }\end{array}$ \\
\hline
\end{tabular}

Tabel 4. Tingkat kerentan seismik setiap daerah di Jawa Barat (Metode Donovan)

\begin{tabular}{cc}
\hline Daerah & $\begin{array}{c}\text { Tingkat Kerentanan } \\
\text { Seismik }\end{array}$ \\
\hline Bandung & $\begin{array}{c}\text { Resiko sedang tiga - } \\
\text { Resiko besar dua }\end{array}$ \\
\hline Bekasi & $\begin{array}{c}\text { Resiko kecil - Resiko } \\
\text { sedang dua }\end{array}$ \\
\hline Bogor & $\begin{array}{c}\text { Resiko kecil - Resiko } \\
\text { sedang tiga }\end{array}$ \\
\hline Ciamis & $\begin{array}{c}\text { Resiko sedang dua - } \\
\text { Resiko sedang tiga }\end{array}$ \\
\hline Cianjur & $\begin{array}{c}\text { Resiko sedang tiga - } \\
\text { Resiko besar tiga }\end{array}$ \\
\hline Cimahi & $\begin{array}{c}\text { Resiko sedang tiga - } \\
\text { Resiko besar satu }\end{array}$ \\
\hline Cirebon & $\begin{array}{c}\text { Resiko kecil - Resiko } \\
\text { sedang satu }\end{array}$ \\
\hline Garut & $\begin{array}{c}\text { Resiko sedang tiga - } \\
\text { Resiko besar tiga }\end{array}$ \\
\hline Indramayu & $\begin{array}{c}\text { Resiko kecil - Resiko } \\
\text { sedang dua }\end{array}$ \\
\hline Resiko kecil - Resiko
\end{tabular}

sedang dua

\begin{tabular}{cc}
\hline Kuningan & $\begin{array}{c}\text { Resiko kecil - Resiko } \\
\text { sedang dua }\end{array}$ \\
\hline Majalengka & Resiko sedang dua \\
\hline Purwakarta & $\begin{array}{c}\text { Resiko sedang dua - } \\
\text { Resiko sedang tiga }\end{array}$ \\
\hline Subang & $\begin{array}{c}\text { Resiko kecil - Resiko } \\
\text { sedang tiga }\end{array}$ \\
\hline Sukabumi & $\begin{array}{c}\text { Resiko sedang dua - } \\
\text { Resiko besar dua }\end{array}$ \\
\hline Sumedang & $\begin{array}{c}\text { Resiko sedang dua - } \\
\text { Resiko sedang tiga }\end{array}$ \\
\hline Tasikmalaya & Resiko sedang tiga - \\
& Resiko besar dua \\
\hline
\end{tabular}

Tingginya nilai percepatan tanah maksimum dan intensitas maksimum gempa yang diperoleh akan berdampak pada tingginya kerentanan seismik di daerah - daerah tersebut.

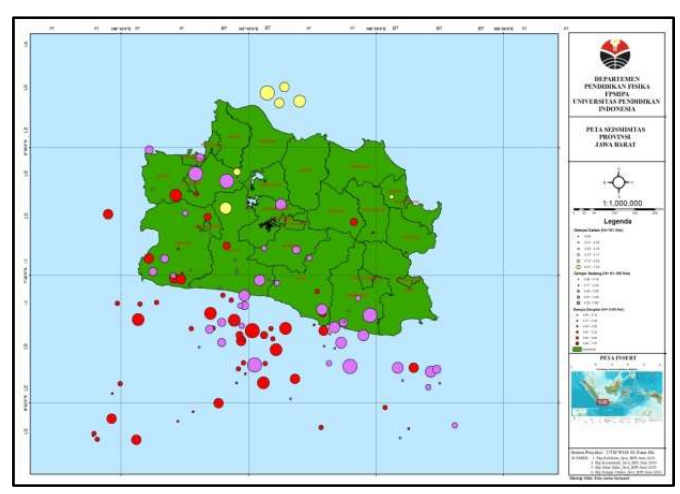

Gambar 11. Peta Seismisitas Jawa Barat Berdasarkan sebaran peta seismisitas pada Gambar 11. menunjukkan frekuensi gempa bumi relatif lebih tinggi di 
wilayah Jawa Barat bagian Selatan kemudian disusul dengan Jawa Barat bagian Timur. Dari data historis NEIC USGS, gempa bumi yang paling merusak pada periode tahun 1974 - 2016 yaitu event gempa yang terjadi pada 2 September 2009 dengan pusat gempa berada di Samudera Hindia $\left(7.78^{\circ}\right.$ LS dan $107.30^{\circ} \mathrm{BT}$ ) pada kedalaman $46 \mathrm{~km}$ barat daya Tasikmalaya, gempa ini bermagnitudo 7.07 SR. Menurut Laporan Harian PUSDALOPS BNPB (Badan Nasional Penanggulangan Bencana) gempa tersebut dirasakan pada daerah Tasikmalaya VII MMI; Cianjur dan Sukabumi V-VI MMI; Bandung, Bogor, Cibinong, Tangerang, Bekasi, Depok, Jakarta, Majalengka dan Cirebon III-IV MMI; Subang II-III MMI. Ada beberapa daerah yang dilanda efek kerusakan paling parah yaitu daerah Cianjur, Garut, Sukabumi, Ciamis, Tasikmalaya dan Bandung.

Berdasarkan frekuensi gempa dan data historis gempa bumi yang merusak di wilayah Jawa Barat secara signifikan dapat dikorelasikan dengan hasil perhitungan dan pemetaan dari kedua metode. Metode yang paling sesuai untuk menentukan tingkat kerentanan seismik di wilayah Jawa Barat dapat diketahui dari hasil perhitungan dan sebaran peta percepatan tanah maksimum dan intensitas maksimum gempa kemudian disesuaikan dengan tingkat kerusakan yang terjadi dari salah satu event gempa yang paling merusak dan frekuensi gempa yang sering terjadi di Jawa Barat periode tahun 1974 2016.

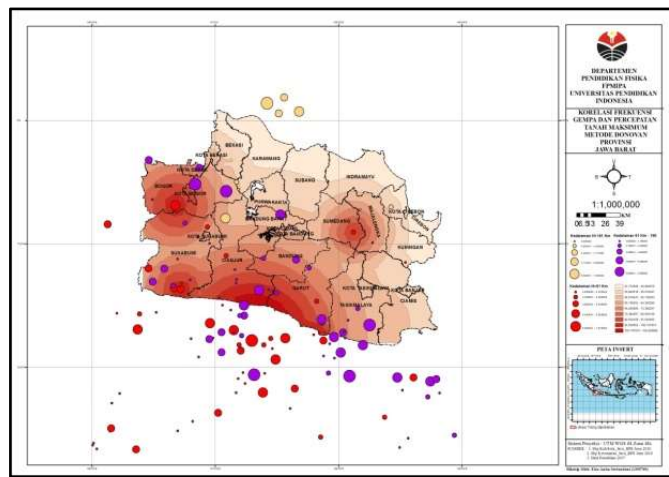

Gambar 12. Korelasi Percepatan Tanah Maksimum Metode Donovan dengan Frekuensi Gempa yang Sering Terjadi di Jawa Barat (Periode Data Gempa 1974 2016)

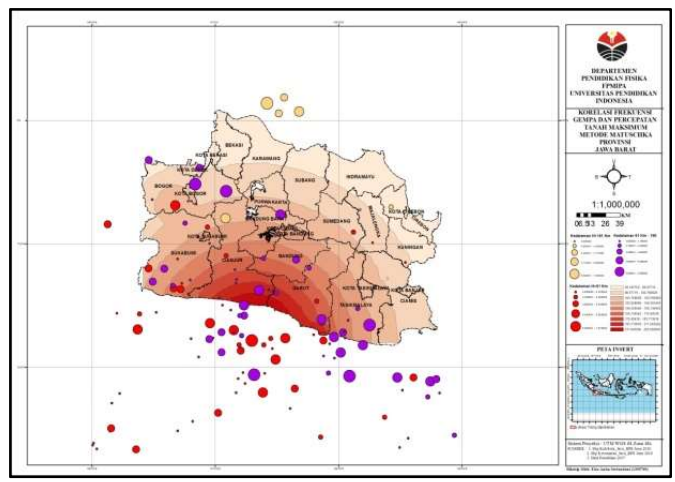


Gambar 13. Korelasi Percepatan Tanah

Maksimum Metode Donovan dengan

Frekuensi Gempa yang Sering Terjadi di Jawa Barat (Periode Data Gempa 1974 2016)

Hasil korelasi dari kedua metode tersebut dengan frekuensi gempa dan salah satu event gempa yang paling merusak dapat ditentukan metode yang paling sesuai dengan keadaan wilayah Jawa Barat yaitu Metode Matuschka. Hal ini dikarenakan metode tersebut memiliki nilai percepatan tanah maksimum dan intensitas maksimum gempa yang tinggi pada daerah Jawa Barat bagian selatan khusunya di daerah yang rata-rata terkena dampak gempa paling parah yaitu Tasikmalaya, Cianjur, Sukabumi, Garut, Ciamis dan Bandung. Sehingga sesuai dengan tingkat kerusakan di daerah tersebut dari salah satu event gempa yang paling merusak di Jawa Barat. Pada pemetaan percepatan tanah maksimum dan intensitas maksimum gempa Metode Matuschka garis konturnya sesuai dengan persebaran titik gempabumi di wilayah Jawa Barat. Hal ini terlihat pada Gambar 13. Namun pada pemetaan metode donovan garis konturnya kurang sesuai dengan keadaan wilayah Jawa Barat, hal ini terlihat pada Gambar 12. Pada gambar tersebut, adanya nilai percepatan tanah dan intensitas gempa yang tinggi di wilayah yang frekuensi gempanya jarang terjadi yaitu Majalengka. Hal ini dikarenakan semakin besar frekuensi gempa yang terjadi semakin besar pula tingkat kerentanan seismiknya.

Hasil perhitungan $b$ value tiap wilayah menggunakan Metode Likelihood maksimum dan standar deviasinya dapat dilihat pada Tabel 5.

Tabel 5. Hasil perhitungan $b$ value dan standar deviasi pada tiap-tiap wilayah.

\begin{tabular}{cccc}
\hline Wilayah & $\hat{a}$ & $\hat{b}$ & $\sigma_{x}$ \\
\hline 1 & 2.58 & 0.40 & 1.03 \\
\hline 2 & 4.6 & 0.71 & 0.75 \\
\hline 3 & 4.49 & 0.79 & 0.55 \\
\hline 4 & 3.9 & 0.56 & 0.92 \\
\hline 5 & 4.42 & 0.70 & 0.55
\end{tabular}

Nilai b merupakan parameter seismologi yang bergantung pada sifat tektonik dan batuan setempat di daerah yang terjadi gempabumi (Nuannin, 2005). Menurut (Scholz, 1968) menyatakan bahwa nilai b yang rendah umumnya berkorelasi 
dengan tingkat stress daerah yang tinggi, sedangkan untuk nilai $b$ yang tinggi sebaliknya. Nilai $b$ yang tinggi berkorelasi dengan wilayah dengan heterogenitas yang besar (Mogi, 1962). Sehingga, banyak ahli mengatakan bahwa nilai $\mathrm{b}$ ini bernilai sekitar 1 atau konstan. Bila ada perbedaan, hal itu dikarenakan penggunaan metode ataupun pengambilan data yang berbeda.

Berdasarkan tabel hasil perhitungan $b$ value untuk masing-masing wilayah diperoleh bahwa nilai b berkisar antara $0.40-0.79$. Berdasarkan hasil perhitungan yang telah dilakukan menunjukkan bahwa harga $b$ terbesar berada pada wilayah 3 yaitu 0.79 dan wilayah dengan nilai $b$ terkecil ada pada wilayah 1 yaitu 0.40. Dari hasil perhitungan wilayah 3 merupakan wilayah yang cukup rawan terhadap gempa bumi dan di wilayah ini juga dilewati oleh sesar baribis yang letaknya di bagian utara Jawa merupakan sesar naik dengan arah relatif barat-timur, membentang mulai dari Purwakarta hingga ke daerah Baribis di KadipatenMajalengka. Namun jika dilihat dari sebaran peta seismisitas Jawa Barat, wilayah ini mempunyai frekuensi gempa yang kecil dibanding wilayah lainnya.
Hal ini dikarenakan pada pembagian wilayah tidak didasarkan pada faktorfaktor lain yang mempengaruhi tingkat resiko gempabumi seperti keadaan dominan tanah, aktivitas kegempaan, kondisi geologis setempat dan sebagainya.

Nilai a untuk distribusi komulatif menggunakan metode likelihood maksimum digunakan untuk menghitung indeks seismisitas dengan $\mathrm{Ms} \geq 4 \quad \mathrm{SR}$. Hasil perhitungan indeks seismisitas dapat dilihat pada Tabel 6 .

Tabel 6. Parameter Aktivitas Seismik dan Nilai Indeks Seismisitas Tiap-Tiap Wilayah.

\begin{tabular}{ccccc}
\hline Wilayah & $\hat{a}_{1}$ & $\hat{a}^{\prime}$ & $\hat{a}_{1}^{\prime}$ & $N_{1}^{(M \geq 4)}$ \\
\hline 1 & 0.96 & 2.54 & 0.92 & 0.21 \\
\hline 2 & 2.98 & 4.4 & 2.78 & 0.9 \\
\hline 3 & 2.88 & 4.24 & 2.62 & 0.29 \\
\hline 4 & 2.28 & 3.79 & 2.17 & 0.85 \\
\hline 5 & 2.8 & 4.21 & 2.59 & 0.62 \\
\hline
\end{tabular}

Indeks seismisitas merupakan normalisasi dari jumlah gempa bumi pertahun. Daerah dengan indeks seismisitas tinggi atau periode ulang rendah merupakan rawan bencana alam. Hasil perhitungan indeks seismisitas 
pertahun untuk 5 wilayah dengan $\mathrm{Ms} \geq 4.0$ SR berkisar antara $0.21-0.85$. Dimana untuk wilayah 4 memiliki indeks seismisitas lebih tinggi dibandingkan wilayah lainnya yaitu sebesar 0.85 . Dengan kata lain wilayah 4 mempunyai tingkat aktivitas gempa yang tinggi dan wilayah tersebut rawan terhadap bencana gempa. Hal ini dapat dibuktikan dengan jumlah frekuensi gempa pada wilayah 4 lebih besar setelah wilayah 2. Wilayah 4 juga termasuk ke dalam wilayah lautan yang berada di atas zona subduksi, yaitu pertemuan antara lempeng Eurasia yang berada sebelah utara dengan lempeng Indo-Australia yang berada di sebelah selatan. Sedangkan untuk wilayah 1 memiliki indeks seismisitas lebih kecil dibandingkan wilayah lainnya yaitu sebesar 0.29 .

Untuk menentukan probabilitas resiko gempabumi diambil periode $\mathrm{T}=14,28$ dan 42 tahun. Sedangkan magnitudo yang dipilih adalah $\mathrm{Ms} \geq 4.0$ SR yang diasumsikan gempa tersebut berpotensi merusak. Parameter indeks seismisitas berguna untuk mengetahui kemungkinan terjadinya gempa merusak paling sedikit satu kali untuk kurun waktu tertentu sehingga dapat diminimalisir kerusakan yang mungkin terjadi. Periode ulang yang pendek umumnya berkorelasi dengan aktivitas kegempaan yang tinggi. Hasil perhitungan kemungkinan kejadian gempa berdasarkan $\mathrm{T}$ (tahun) dan nilai rata-rata periode ulang $(\Theta)$ dari gempa yang merusak untuk setiap wilayah dapat dilihat pada Tabel 7.

Tabel 7. Kemungkinan Kejadian Gempa Berdasarkan $\mathrm{T}$ (tahun) dan nilai rata-rata periode ulang pada tiap-tiap wilayah

\begin{tabular}{cclccc}
\hline $\begin{array}{c}\text { Wil } \\
\text { aya } \\
\text { h }\end{array}$ & $\begin{array}{c}\text { Indeks } \\
\text { Seismisi } \\
\text { tas } \\
\text { Gempa } \\
\text { Merusak }\end{array}$ & $\begin{array}{l}\mathrm{T}=1 \\
\text { Thn } \\
(\%)\end{array}$ & $\begin{array}{c}\mathrm{T}=28 \\
\mathrm{Thn} \\
(\%)\end{array}$ & $\begin{array}{c}\mathrm{T}= \\
42 \\
\mathrm{Thn} \\
(\%)\end{array}$ & $\begin{array}{c}\Theta \\
(\mathrm{T} a \mathrm{u})\end{array}$ \\
\hline 1 & 0.03 & 34.3 & 56.8 & $\begin{array}{c}71 . \\
6\end{array}$ & 33 \\
& & & & 61. & 33 \\
\hline 2 & 0.03 & 34.3 & 56.8 & $\begin{array}{c}71 . \\
6\end{array}$ & \\
\hline 3 & 0.008 & 10.5 & 20 & 28. & 125 \\
& & & & 5 & \\
\hline 4 & 0.06 & 56.8 & 81.4 & 91. & 17 \\
& & & & 9 & \\
\hline 5 & 0.025 & 29.5 & 50.3 & 65 & 40 \\
\hline
\end{tabular}

Berdasarkan perhitungan, periode ulang berkisar antara 17 tahun sampai dengan 125 tahun seperti terlihat pada Tabel 7. Dari hasil perhitungan dapat dilihat bahwa tingkat resiko gempa yang tinggi terdapat pada periode yang singkat 
dengan harga kemungkinan yang besar.

Hal tersbut terlihat pada hasil perhitungan wilayah 4 , pada wilayah ini meliputi kawasan wilayah lautan di Jawa Barat bagian selatan yang berada dekat dengan kawasan pantai selatan pada daerah Cianjur, Garut dan Sukabumi dan sebagainya. Hal ini sejalan dengan hasil tingkat kerentanan seismik dari percepatan tanah maksimum dan intensitas maksimum gempa yang tinggi mencangkup kawasan bagian selatan tepatnya di daerah Cianjur. Sedangkan sebaliknya tingkat resiko gempa yang rendah terdapat pada wilayah 3 , yang meliputi daerah Jawa Barat bagian Timur termasuk Majalengka, Cirebon, Sumedang dan sebagainya dimana untuk kemungkinan rendah berkorelasi dengan periode yang lama.

\section{Kesimpulan}

1. Percepatan tanah maksimum berkisar di Jawa Barat berkisar antara 27.76 Gal - 110.01 Gal dan nilai intensitas maksimum gempanya berkisar antara VI MMI - VIII MMI dengan metode Donovan. Sedangkan untuk metode Matuschka diketahui nilai percepatan tanah maksimum di Jawa Barat berkisar antara 69.16
Gal - 229.55 Gal dan nilai intensitas maksimum gempanya berkisar antara VI MMI - VIII MMI.

2. Tingkat kerentanan seismik tertinggi berada di daerah Cianjur, kecamatan Cidaun tepatnya pada koordinat $7^{\circ} 28^{\prime} 39.047$ LS dan 107'16'44.213'” BT. Tingginya kerentanan seismik diakibatkan oleh tingginya nilai percepatan tanah maksimum dan intensitas maksimum gempa yang diperoleh pada daerah tersebut juga faktor geologi yang berada pada daerah tersebut.

3. Hasil korelasi dari Metode Donovan dan Metode Matuschka dengan frekuensi gempa dan salah satu event gempa yang paling merusak dapat ditentukan metode yang paling sesuai dengan keadaan wilayah Jawa Barat yaitu Metode Matuschka.

4. Hasil perhitungan $\mathrm{b}$ value untuk 5 wilayah dengan $\quad \mathrm{Ms} \geq 4.0 \quad \mathrm{SR}$ nilainya beriksar $0.40 \quad-0.79$ dengan indeks seismisitas pertahun berkisar antara $0.21-0.85$.

5. Probabilitas terbesar terhadap kejadian gempa berada pada wilayah 4 untuk periode 42 tahun 
sebesar $91.9 \%$ dengan periode ulang gempa tercepat yaitu 17 tahun. Periode ulang yang pendek biasanya berkorelasi dengan wilayah dengan aktivitas kegempaan yang relatif tinggi, dan sebaliknya.

\section{Referensi}

1. Budiman, Arif. dkk. (2011). Analisis Periode Ulang dan Aktivitas Kegempaan Pada Daerah Sumatera Barat Dan Sekitarnya. Universitas Andalas. Padang.

2. Douglas, John. (2011). Groundmotion Prediction equations 19642010. Berkeley: BRGM.

3. Edwiza, Daz. (2008). Pemetaan Percepatan Tanah Maksimum dan Intensitas Seismik Kota Padang Panjang Menggunakan Metode Kanai. Universitas Andalas. Padang

4. Fauzi. dkk. (2012). Aplikasi Sistem Informasi Geografi Untuk Peta Bencana Alam Di Indonesia. Jakarta : Badan Meteorologi Dan Geofisika

5. Haris, Adam. (2013). Analisis Percepatan Getaran Tanah Maksimum Wilayah Yogyakarta
Dengan Metode Atenuasi Patwardhan. Journal Neutrino Vol 5, No. 2 April 2013.

6. Indarto, Himawan. (2002). Rekayasa Gempa. Jurusan Teknik Sipil Universitas Diponegoro . Semarang.

7. Mogi, K. (1962). MagnitudeFrequency Relationship for Elastic Shocks

Accompanying Fractures of Various Materials and Some Related Problems in Earthquakes. Bull. Earthquake Res. Inst. Univ. Tokyo, 40, 831883.

8. Nuannin, Paiboon. dkk. (2005). Spatial and Temporal b-Value Anomalies Precedding the Devastating off Coast of $N W$ SumatraEarthquake of December 26, 2004, Geophysical Research Latter 32, L11307.

9. Peter, W.M., 1926-1956, Statistical Analysis of Earthquake Occurrence in Japan, BIISEE. Vol. 2 (1965), pp. 1-27

10. Sari, Yulia. (2012). Studi Percepatan Gempa Maksimum Untuk Zona Peta Gempa Indonesia Di Kota Banda Aceh. Institut Teknologi Surabaya. Surabaya. 
11. Scholz, C.H. (1968). The Frequency-Magnitude Relation of Microfracturing in

Rock and Its Relation to Earthquakes. Bull. Seismol. Soc. Am., 58, 399-415.

12. Utsu, T. (1961). A Method in Determining the value of $b$ in $a$ formula $\log N=a-b M$ Showing the magnitude frequency for earthquakes. Geophys Bull. Hokkaido Univ.

13. Vertika, Angga. dkk. (2011). Tatanan Tektonik Jawa, Bali dan NTB. (Laporan PPL). Akademi Meteorologi Klimatologi Geofisika. Jakarta. 